\title{
Historyk Andrzej Wyczański kolejnym doktorem honoris causa bialostockiego uniwersytetu
}

Dnia 1 czerwca 1999 r. w odbyła się uroczystość wręczenia dyplomu doktora honoris causa Uniwersytetu w Białymstoku jednemu z najwybitniejszych uczonych polskich, profesorowi Andrzejowi Wyczańskiemu, członkowi rzeczywistemu PAN i zarazem pracownikowi białostockiego Instytutu Historii. W tym uroczystym dniu w Auli Wydziału Humanistycznego obok dostojnego Jubilata, senatu uczelni zasiedli także licznie przybyli z kraju i zagranicy Jego przyjaciele, koledzy, uczniowie, delegacje reprezentujące PAN $\mathrm{i}$ inne ośrodki badawcze (w tym przedstawiciel Rektora Université de Paris-Sorbonne - Paris IV), władze administracyjne i samorządowe województwa podlaskiego i miasta Białegostoku, rektorzy białostockich uczelni oraz studenci.

Uroczystość otworzył JM Rektor prof. Adam Jamróz, który przywitał przybyłych gości i poinformował, iż Senat Uniwersytetu w Białymstoku na wniosek Rady Wydziału Prawa, do której z taką inicjatywą wystąpiła Rada Naukowa Instytutu Historii w uznaniu wybitnych osiągnięć naukowych, roli w środowisku, zasług na polu kierowania nauką i wysiłków współtworzenia samodzielnej uczelni w Białymstoku postanowił nadać prof. Andrzejowi Wyczańskiemu tytuł doktora honoris causa najmłodszego w kraju - Uniwersytetu w Białymstoku. Życiorys doktora honorowego przedstawił Dziekan Wydziału Prawa prof. Stanisław Prutis. Przypomnial on studia historyczne Jubilata na tajnym Uniwersytecie Warszawskim, a następnie Jagiellońskim i początki pracy zawodowej - asystenta u prof. Józefa Feldmana w Krakowie i od 1946 r. u prof. Tadeusza Manteuffla w Instytucie Historycznym UW, a także wieloletnią bo trwającą od 1953 r. pracę w Instytucie Historii PAN. Przedstawił osiąganie przez doktora kolejnych awansów naukowych (prof. nadzwyczajny w 1963 r., prof. zwyczajny w 1971 r.), Jego związki z nauką zachodnią, pracę organizacyjną w IH PAN (kierownik Zakładu Dziejów Polski Przedrozbiorowej i jej Kultury, w jego ramach także kierownik Pracowni Dziejów Rzeczypospolitej Szlacheckiej, od 1977 r. kierownik Pracowni Historii Polski Nowożytnej) i Bibliotece Narodowej w Warszawie (kierownik Stacji Mikrofilmowej 1949-1959), kierowanie Wydziałem I PAN (1990-1992) i pełnienie funkcji wiceprezesa i sekretarza naukowego PAN (1993-1995). W bogatym i jakże pracowitym życiorysie Profesora nie zabrakło pracy społecznej na rzecz środowiska. Przez 17 lat (1971-1987) był prezesem Towarzystwa Miłośników Historii w Warszawie. Kierował również przez wiele lat Ogólnopolskim Komitetem Olimpiady Historycznej. Ostatnio współdziałał owocnie na rzecz powołania Katedry Kultury Polskiej na Uniwersytecie Hebrajskim w Jerozolimie. 
W swoim wystąpieniu prof. S. Prutis zwrócił również uwagę na bogaty wątek białostocki w życiorysie Jubilata. Od 1974 r. współorganizował białostockie środowisko naukowe historyków kształcąc studentów i kadrę naukową. Pod kierunkiem Profesora powstało ponad 100 prac magisterskich i cztery doktorskie w Białymstoku (ogółem10), a kolejne są na ukończeniu. W latach 1985-1991 kierował Instytutem Historii, zaś od 1991 r. jest przewodniczącym jego Rady Naukowej.

Z uroczystą laudacją jako promotor doktoratu honorowego wystąpił Dziekan Wydziału Humanistycznego prof. Adam Dobroński. W serdecznych i pełnych ciepła słowach ukazał sylwetkę dostojnego Jubilata nie tylko jako lidera nauki polskiej, autorytetu naukowego RP, reformatora PAN, ale przede wszystkim jako człowieka ogromnie życzliwego i przyjaznego dla innych ludzi, prawdziwego humanisty kończącego się XX stulecia.

Następnie głos zabrali opiniodowacy w przewodzie doktoratu honorowego: profesorowie Janusz Tazbir z PAN, Henryk Samsonowicz z UW i Stefan Meller z Uniwersytetu w Białymstoku. Wszyscy recenzenci zgodnie podkreślali ogromny i różnorodny tematycznie dorobek naukowy, przełamywanie stereotypów, oryginalność ustaleń, nowatorstwo metodyczne wielu prac, uznanie i wysoką pozycję w nauce światowej prof. A. Wyczańskiego. Po zakończeniu wystąpień opiniodawców w podniosłej i uroczystej atmosferze promotor wręczył Profesorowi dyplom doktora honoris causa Uniwersytetu w Białymstoku.

W dalszej części uroczystości o pracy i zasługach doktora honorowego na rzecz mieszkańców ziem północno-wschodniej Polski mówili: wicewojewoda podlaski mgr Józef Klim, wiceprezydent miasta Białegostoku mgr Krzysztof Teodoruk i marszałek województwa podlaskiego Sławomir Zgrzywa. Słowa uznania i życzenia pod adresem dostojnego Jubilata skierowali obecni na sali: prezes PAN prof. Stanisław Mossakowski, sekretarz Wydziału I prof. Jerzy Z. Holzer, dyrektor Instytutu Historii PAN prof. Stanisław Bylina oraz prof. Jean Bérenger z paryskiej Sorbony (Paris IV).

Doktor honorowy Uniwersytetu w Białymstoku otrzymał także dziesiątki telegramów z serdecznymi słowami pełnymi gratulacji, pozdrowień i życzeń w tym: od najwyższych władz państwowych Prezydenta i Premiera RP; Ministrów - Spraw Zagranicznych, Edukacji Narodowej, Komitetu Badań Naukowych; od społeczności uniwersytetów i szkół wyższych, Polskiego Towarzystwa Historycznego, innych towarzystw naukowych oraz od bardzo wielu przyjaciół i kolegów z kraju i zagranicy.

Bardzo ciepło zabrzmiał głos najmłodszych uczniów, jeszcze studentów Profesora, w imieniu których przemawiał Piotr Guzowski. Swoje spotkanie z Profesorem i Mistrzem na pierwszym seminarium magisterskim w Białymstoku przed dwudziestu laty wspominał inny uczeń prof. Cezary Kuklo. On także wspólnie z dr Anną Kamler wręczyli okolicznościową księgę pt. Między politykq a kulturq wydaną przez Wydawnictwo Naukowe PWN, dedykowaną Andrzejowi Wyczańskiemu w 75-lecie urodzin i 50-lecie pracy naukowej.

$\mathrm{Na}$ zakończenie uroczystości głos zabrał Jubilat i doktor honorowy Uniwersytetu w Bialymstoku. W bardzo osobistym, przepełnionym wzruszeniem wystąpieniu prof. A. Wyczański, chyba przez pewną przekorę do wcześniejszych wystąpień, mówił o tym czego nie udało mu się osiągnąć w pracy naukowej i jakich tematów nie zrealizował do tej pory. Uważni słuchacze, w tym najmłodsi - studenci mogli się przekonać jak szerokie perspektywy mogą mieć badania nad dziejami społeczeństwa, w tym wypadku społeczeństwa staropolskiego proponowane i postulowane przez uczonego tej miary co Profesor Andrzej Wyczański. 
Tą część uroczystości zakończył Gaudeamus igitur w wykonaniu chóru uniwersyteckiego. Po nim ustawiła się długa k lejka osób z życzeniami i gratulacjani, składanych Jubilatowi przy lampce wina. Nie obyło się bez nich także w trakcie oficjalnego obiadu wydanego na cześć dokt•ra honoris causa i Jubilata przez władze Uniwersytetu w Białymstoku.

$\mathrm{Na}$ księgę Między polityka a kulturą składają się następujące prace naukowe: Henryk Samsonowicz, Polska widziana przez Hanze w I polowie XVI wieku; Maciej Serwański, Usytuowanie Rzeczypospolitej szlacheckiej w Europie z perspektywy Paryza. Uwarunkowania geopolityczne i stosunki międzynarodowe; Stanisław Grzybowski, Irlandia u progu dziejów nowożytnych: między anarchiq a niewola; Janusz Małlek, Jan Dantyszek a Prusy Ksiazęce w latach 1525-1548; Igor Kąkolewski, Dwór czy diug monarszy nerwem państwa?, czyli o dochodach $i$ wydatkach państwowych Prus Ksiazęcych (1550-1643); Jean Bérenger, La Prusse ducale au début du XVIIe siècle; Walter Leitsch, Pläne der Jahre 1609-1632, den Prinzen Wladystaw zu verheiraten; Daniel Tollet, La reconquè catholique en Europe centrale (La Pologne d'Andrussowo à Carlowitz); Anna Sucheni-Grabowska, Rola mandatu poselskiego w dawnej Polsce na tle porównawczym; Jacek Staszewski, Zmiana zakresu oceny unii polsko-saskiej; Jerzy Michalski, Czy ,,ius retractus”' zniesione zostato w 1768 roku?; Hanna Zaremska, Jan Dtugosz o tumulcie krakowskim w 1407 roku; Jakub Gøldberg, Polacy - Żydzi - Niemcy w Polsce $w$ XVII-XVIII wieku; Anna Laszuk, Taryfy podatkowe zwierciadtem struktur spolecznych; Cezary Kuklo, Ze studiów nad stuzba domowa $w$ miastach Polski przedrozbiorowej; Antoinette Fauve-Chamoux, La cohabitation des frères et soeurs en France préindustrielle; Joseph Goy, Société marginale, colonisation et reproduction familiale au Québec et en Amerique. Le modéle Saguenay; Alina Czapiuk, O plonach zbóż $w$ Polsce i w Wielkim Księstwie Litewskim w XVI i XVII wieku; Barbara Stępniewska-Holzer, Ostatnie dekady folwarku pańszczyźnianego na Witebszczyźnie; Juliusz Łukasiewicz, Rolnictwo na ziemiach polskich przed stu laty (niektóre problemy); Andrzej Jezierski, Cecylia Leszczyńska, Bezrobocie utajone w rolnictwie polskim; Jan Kofman, Wielki kapitat wobec interwencji państwa w gospodarkę (Polska 1919-1939); Jerzy Topolski, Posty w Polsce w końcu średniowiecza i w czasach nowożytnych $i$ ich rola kulturowa; Jean-Louis i Maria Flandrin, Regards occidentaux sur les banquets de Pologne aux XVIe, XVIIe et XVIIIe siècles; Janusz Tazbir, Szlachic w lesie i o lesie; Małgorzata Wilska, Blazen dworski w świetle rachunków królewskich - ,curiositas” polskie czy europejskie?; Halina Manikowska, Noc listopadowa 1526 roku we Wroclawiu. (Czyli o pożytkach plynacych z reformacyinego obrazoburstwa dla badań mediewistycznych); Anna Kamler, Na marginesie listów dedykacyjnych; Adam Manikowski, Budzet jednego życia, czyli o mecenacie artystycznym senatora florenckiego w XVII wieku; Dariusz Główka, Między teologiq a historiq i prawem. Księgozbiór Macieja Garnysza podkanclerzego i biskupa chelmskiego (1790 rok); Stefan Meller, Polski Uniwersytet Ludowy w Paryżu. Rok 1917; Janusz Żarnowski, Kryzys i perspektywy historii spoleczne; Monika Senkowska-Gluck, Rewolucja francuska 1789 roku przed sadem historii; Antoni Mączak, Dylematy historycznych badań porównawczych; Halina Parafianowicz, Legenda Woodrow Wilsona w międzywojennej Czechostowacji.

Cezary Kuklo 